\title{
Viviparous sea snakes can be used as bioindicators for diverse marine environments
}

\author{
Arne Redsted Rasmussen ${ }^{*}$, Anders Hay-Schmidt ${ }^{2}$, Farnis Boneka ${ }^{3}$, Morten E. Allentoft ${ }^{4,5}$, Kate Laura \\ Sanders $^{6}$, and Johan Elmberg ${ }^{7}$
}

\begin{abstract}
Shallow tropical marine ecosystems are under great anthropogenic pressure due to habitat destruction, overfishing, shrimping, climate change, and tourism. This is an issue of global concern as such environments hold a tremendous biodiversity much of which remains to be described. The present situation urgently calls for time- and resource-efficient methods to identify and delineate the most valuable remaining areas and to set up priorities for their management and conservation. Using indicator species can be a way to accomplish this goal. In this paper we evaluate whether viviparous sea snakes can serve as bioindicators for other rare or cryptic tropical marine fauna. Based on seven generally acknowledged criteria for bioindicators, we argue that using viviparous sea snakes as bioindicators can help monitoring marine habitats to gauge the effects of climate change, habitat change and loss, decline in biodiversity and other anthropogenic changes. However, to maximize their efficacy as bioindicators, deeper knowledge about viviparous sea snakes natural history is urgently needed. Topics for expanded research programs include the taxonomy of some groups, their breeding and feeding biology, habitat selection and their geographical distribution. Despite these gaps in our understanding, we argue that viviparous sea snakes can be utilized as bioindicators of marine ecosystem health.
\end{abstract}

Keywords: anthropogenic changes, conservation, herpetology, marine habitat, monitoring

\section{Introduction}

With the current rate of biodiversity loss and the fact that there are hardly any geographical areas not subjected to global change, it is crucial to use existing information on representative species to evaluate the conservation status of a variety of ecosystems (Alcala \& Russ, 1990; Brischoux et al.,

\footnotetext{
${ }^{1}$ The Royal Danish Academy, Institute of Conservation, Esplanaden 34 1263 Copenhagen K, Denmark

${ }^{2}$ Department of Odontology, Faculty of Health and Medical Sciences, University of Copenhagen 1165 Copenhagen N, Denmark

${ }^{3}$ Marine Biology Laboratory, Faculty of Fisheries and Marine Sciences, Sam Ratulangi University, Manado, North Sulawesi, Indonesia

${ }^{4}$ Trace and Environmental DNA (TrEnD) Laboratory, School of Molecular and Life Sciences, Curtin University, Kent Street, 6102 Perth, Australia ${ }^{5}$ Lundbeck Foundation GeoGenetics Centre, GLOBE Institute, University of Copenhagen, Øster Voldgade 5-7, 1350 Copenhagen K, Denmark.

${ }^{6}$ School of Earth and Environmental Sciences, University of Adelaide, South Australia 5000, Australia

${ }^{7}$ Aquatic Biology and Chemistry, Kristianstad University, SE-291 88 Kristianstad, Sweden

*Corresponding email: arr@kadk.dk

Date Submitted: 11 July 2019

Date Accepted: 1 February 2021
}

2009a; Dudgeon et al., 2006; Elfes et al., 2013; Russ \& Alcala, 2003; Russ et al., 2015; Sutherland et al., 2009; Vitousek et al., 1997; Zwickl, 2006). Most marine species are cryptic and difficult to sample and/or monitor, calling for the use of indicator species in a fashion that has been successfully implemented in conservation and management of forest and agricultural ecosystems. As a case in point, there is an urgent need to develop bioindicators for tropical shallow marine environments. Previous research embracing a wide range of ecosystems and taxonomic groups indicates that dependable and useful bioindicator taxa need to fulfil as many as possible of the following seven criteria (McGeoch, 1998; Niemelä, 2000; Noss, 1990; Pearson, 1994; Pearson \& Cassola, 1992):

1.well-known and stable taxonomy

2.well-known ecology and natural history

3.easy to survey

4.higher taxa widely distributed geographically and over a breadth of habitats

5.diverse number of species specializes and sensitive to habitat changes

6.patterns observed in indicator taxa are also observed in related and unrelated taxa

7.present or potential economic importance 
More specifically, in order for organisms to be useful bioindicators they should be taxonomically well-resolved, widely distributed and their ecology should be sufficiently known to allow comparisons among sites. It is futile to believe that a single group of organisms or a single species can reflect the abundance and distribution of all other co-occurring taxa in a comprehensive way (Bilton et al., 2006; Carignan \& Villard, 2002; Fleishman et al., 2005; Heino, 2010). Nevertheless, biodiversity monitoring in forest and riverine ecosystems amply demonstrates that some organisms are indeed efficient indicators for a wide range of co-occurring taxonomic groups (Heino, 2010). Coral reefs, river mouths, mangroves and other shallow tropical marine waters are extremely diverse ecosystems that are subject to rapidly increasing and destructive anthropogenic pressure. These habitats are in desperate need of improved and accurate biological monitoring (Alcala \& Russ, 2006; Bishop \& Alsaffar, 2008; Briers \& Biggs, 2003; Brischoux et al., 2009a, 2011a; Cherel \& Hobson, 2007; Ellis et al., 2012; Hindell et al., 2003; Ineich et al., 2007; Salas et al., 2004; Simboura \& Zenetos, 2002; Weeks et al., 2010). However, tropical seas lag behind when it comes to biodiversity monitoring, largely because the ecological roles and trophic interrelationships of their organisms are less well understood. For example, many species escape observation and study because they are sheltered in the coral matrix, or in mud and sand holes or rocky bottoms. Taxa used as indicators also need to include species that show some degree of ecological specialization, sufficient to reflect relevant qualities of different trophic levels and taxonomic groups of the ecosystem under investigation (Brischoux et al., 2009a).

Sea snakes are a group of widely distributed top predators inhabiting shallow waters from the western Indian Ocean to the eastern Pacific Ocean (Rasmussen et al., 2011a). The 70 species of sea snakes share many adaptations and ecological roles. They are paraphyletic, comprising amphibious oviparous sea kraits (the 'Laticauda Group:' 8 species) and fully aquatic viviparous sea snakes (Hydrophiinae: - about 63 species) (Elfes et al., 2013; Nankivell et al., 2020). Recent research indicates that sea kraits (Laticauda spp.), by virtue of their diet specialised on eels, bear the promise of being useful bioindicators for surveying Anguilliform fish (eel-like fish) in coral reefs (Brischoux et al., 2009a; Ineich et al., 2007; Reed et al., 2002; Seret et al., 2008). Several species of viviparous sea snakes cooccur with sea kraits, and the former show a variety of additional morphological and behavioural adaptations for catching prey in structurally complex and taxonomically diverse tropical shallow marine environments such as coral reefs (Sanders et al., 2013a; Udyawer et al., 2016a). To explore the utility of viviparous sea snakes in these marine environments, we here contrast the current state of our present knowledge of their natural history with the seven general criteria for bioindicators presented by Pearson (1994). To illustrate these points, we use the knowledge about the sea kraits value as bioindicator as a contrast to the information we have about viviparous sea snakes.

\section{Criterion 1: well-known and stable taxonomy}

Most authors regard the eight recognized species of oviparous sea kraits as belonging to the same genus: Laticauda (Cogger \& Heatwole, 2006; Gherghel et al., 2016; Heatwole et al., 2005; McCarthy, 1986; Slowinski, 1989), and as late as in 2005 and 2006 newly described species were added to the genus (Cogger \& Heatwole, 2006; Heatwole et al., 2005). Only very few authors have suggested the existence of more than one genus of sea kraits (Kharin \& Czeblukov, 2006; Kharin \& Czeblukov, 2013; Wells, 2007), so in general this group's taxonomy is regarded as stable.

In contrast, the taxonomy and phylogeny of viviparous sea snakes have been debated for many years and has been developed significantly since the first comprehensive treatment by M.A. Smith (1926); (Kharin \& Czeblukov, 2006, 2009; Lukoschek \& Keogh, 2006; Rasmussen, 1997, 2002; Rasmussen et al., 2011a; Sanders et al., 2008; Smith, 1926; Voris, 1977). However, the last six years have seen an increasing consensus about phylogeny as well as taxonomy in this group (Lee et al., 2016; Rasmussen et al., 2014; Sanders et al., 2013b). At present, more than $85 \%$ of all known species have been included in phylogenies using either mitochondrial or genomic DNA (Lee et al., 2016; Sanders et al., 2013b). As a result, most authors now recognize 7 genera within the viviparous sea snakes: Aipysurus and Emydocephalus, collectively called the Aipysurus Group, which forms the sister group of all other viviparous sea snakes and is found mainly in the Australian region (Fig. 1; see Lee et al. [2016] for a recent phylogenetic study). Although not functionally treated as sea snakes here, the semi-aquatic monotypic genera Ephalophis, Hydrelaps and Parahydrophis, all found in Australian and New Guinea waters, are robustly placed at the base of the branch leading to the two last genera in the viviparous sea snakes group. The final group is composed of the genera Microcephalophis, mainly occurring in Asia, and Hydrophis, which occurs in both Asian and Australian regions (Sanders et al., 2013b). Based on the phylogeny in Sanders et al. (2013a) and Lee et al. (2016), a revised taxonomy of viviparous sea snakes invalidates the formerly recognized genera Acalyptophis, Astrotia, Disteira, Enhydrina, Kerilia, Lapemis, Kolpophis and Thalassophina, because these taxa are nested within the genus Hydrophis. Instead of erecting many new 


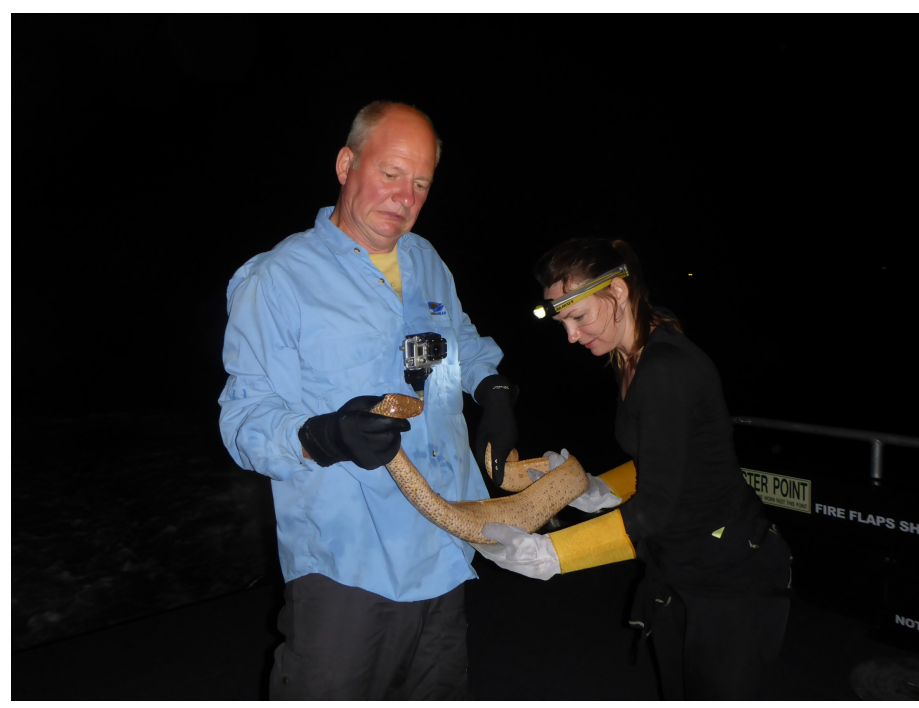

Figure 1. Two of the authors handling an Aipysurus laevis (Broome, Northern Australia).

genera, a single genus Hydrophis is now recognised for all these taxa (Lee et al., 2016; Sanders et al., 2013b). In taxonomic arrangements resulting from phylogenetic analyses of viviparous sea snakes discussed above, very few species have uncertain phylogenetic placement, and this group is now regarded as more stable than ever before. Stable taxonomy allows species to be used for repeated monitoring, without the worry that the taxonomy will undergo a drastic re-arrangement making data incomparable over time. Stable taxonomy also establishes whether a particular group is geographically situated on a large diversity of ecosystems for which it can be used as bioindicator. However, there is no doubt that research in the near future will add new species to the Hydrophis Group, as new areas are investigated and more specimens are analysed with respect to morphological traits and genetic variation (Nankivell et al., 2020; Udyawer et al., 2018). Many widespread species-complexes include multiple cryptic species, many of which possess narrow distributions (Lukoschek, 2018a; Sanders et al., 2014; Udyawer et al., 2018; Ukuwela et al., 2017) based on preliminary molecular studies conducted by K.L. Sanders and colleagues. An additional 20 viviparous sea snake species remain to be described, increasing global marine snake diversity potentially by as much as $30 \%$ (Udyawer et al., 2018).

In the last few years, several new checklists and identification keys based on morphology have been published providing a solid regional base for sea snake identification fulfilling Criterion 1 (Alcala, 1986; Bussarawit et al., 1989; Buzas et al., 2019; Cao et al., 2017; Carpenter et al., 1997; Cogger \& Heatwole, 2006; Ganesh et al., 2019; Guinea, 1994; Ineich \& Laboute, 2002; Ineich \& Rasmussen, 1997; Khan,
2004; Leviton et al., 2014, 2018; Mao \& Chen, 1980; Mirtschin et al., 2017; Murphy et al., 1999; Rasmussen, 2001; Rasmussen et al., 2011b, 2014; Rezaie-Atagholipour et al., 2016; Somaweera \& Somaweera, 2009; Weinell et al., 2019).

\section{Criterion 2: well-known ecology and natural history}

\section{Breeding biology}

Sea kraits forage at sea but lay their eggs on land, although detailed information about the breeding strategy of some species is still scarce (Bonnet et al., 2014). Mark-recapture studies in New Caledonia show that female Laticauda saintgironsi migrate more than $50 \mathrm{~km}$ seasonally between their home areas and coastal nurseries to lay eggs (Bonnet et al., 2014). Coastal nurseries attracting females from a larger area have not yet been described for other Laticauda species, but in the Philippines Laticauda semifasciatus and L. laticaudata lay eggs in crevices on the rough surface of the walls of caves (Bacolod, 1983) and in New Caledonia L. laticaudata and $L$. saintgironsi lay eggs in seabird burrows (Procellariiformes), in tree cavities, and in fields of large stone blocks. The above-mentioned habitats are also used as shelter by sea kraits (Brischoux \& Bonnet, 2009; Ineich \& Laboute, 2002). The information about seasonality of reproduction in sea kraits is scattered, but indicates that the breeding season follows the warm season in northern and southern populations, whereas it is more diffuse and spread out over time in areas closer to the equator (Bacolod, 1983; Bonnet, 2012; Bonnet et al., 2014; Brischoux \& Bonnet, 2009; Brischoux et al., 2011b; Brongersma, 1956; Greer, 1997; Pernetta, 1977; Saint Girons, 1990; Shetty \& Shine, 2002a; Shine et al., 2002a; Toriba \& Nakamoto, 1987; Tu et al., 1990).

The viviparous sea snakes give birth in water and they rarely or never come ashore. In this group too, there are examples of 'nursery areas' where many females congregate to give birth (Porter et al., 1997; Udyawer et al., 2016b; Voris, 2015), but seasonal patterns of reproduction and litter size in viviparous sea snakes remain poorly understood, despite some published data (Bacolod, 1990; Bergman, 1943; de Silva et al., 2011; Fry et al., 2001; Greer, 1997; Lemen \& Voris, 1981; Masunaga \& Ota, 2003; Mirtschin et al., 2017; Rasmussen, 1989; Rasmussen et al., 2011a; Voris \& Jayne, 1979; Wall, 1921; Ward, 2001).

Long term studies are urgently needed to obtain a more complete picture of breeding biology in viviparous sea snakes (Udyawer et al., 2018) as some species utilize nursery sites that are suitable for a range of other species sensitive to anthropogenic threats (e.g. fishing). Very likely, locating and delineating nursery areas of viviparous sea snakes can help identify areas suitable for a range of other cryptic species. It is 
also important to understand the seasonality of the reproductive effort and use of nursery sites by juveniles as change to cyclic seasonal occurrence of juveniles may indicate a disruption in the ecosystem that might influence other co-occurring species.

\section{Feeding Biology}

In several recent studies reviewed by Brischoux et al. (2009a), stomach contents of sea kraits (Laticauda spp.), which forage at sea, revealed more than 45 species of eels (Anguilliformes) of which 15 were new to science (Brischoux \& Bonnet, 2009; Brischoux et al., 2007ab, 2009ab; Ineich et al., 2007). Tabata et al. (2017) investigated three species of Laticauda in Japan and confirmed that L. colubrina and $L$. laticaudata are specialized for feeding on eels, whereas $L$. semifasciata consumes various other families of fish as was reported from Taiwan (Mao \& Chen, 1980).

Information about the diet of viviparous sea snakes is mainly based on gut content analyses (Glodek \& Voris, 1982; Greer, 1997; McCosker, 1975; Rasmussen, 2001; Voris \& Voris, 1983; Voris et al., 1978). Although there is comprehensive literature available about diet, such information is limited to only a few species (Fig. 2). Interestingly, from the perspective of bioindicator utility, several species appear to have a specialised diet, such as fish eggs, catfish, gobies, or eels, whereas others are more generalist feeders, consuming fish from more than 10 families (Voris \& Voris, 1983).

Many viviparous sea snakes feed on secretive fish that spend most or all of their life hidden in crevices in reefs or in mud burrows (McCosker, 1975; Sanders et al., 2013b; Voris \& Voris, 1983). Fishes with these kinds of secretive lifestyle are

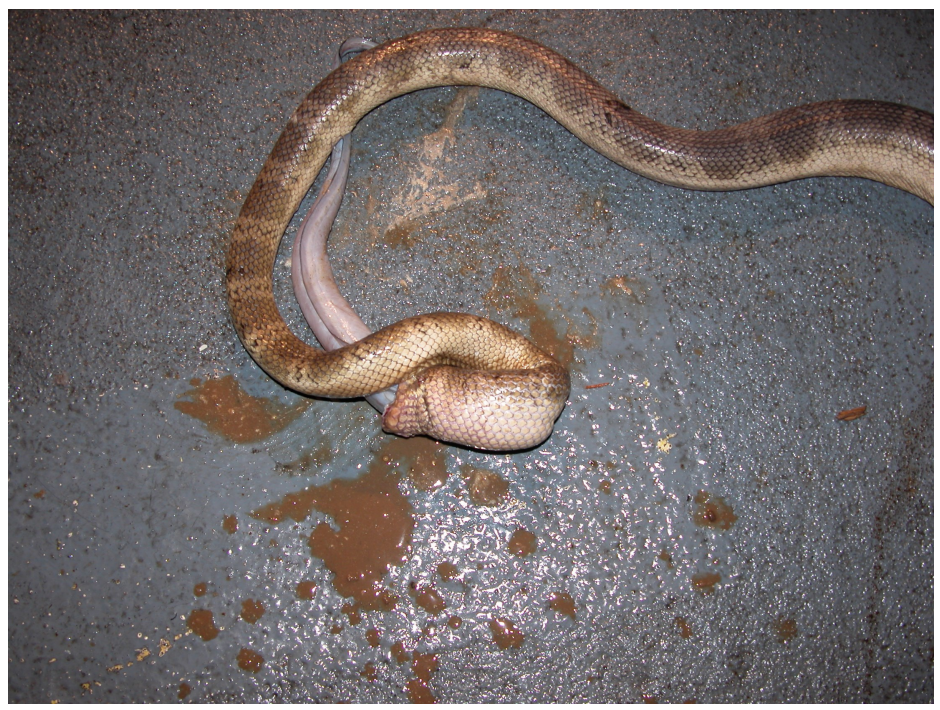

Figure 2. Hydrophis elegans, captured on the sea surface above depths of $145 \mathrm{~m}$ regurgitated a benthic eel indicating recent successful foraging on the sea floor (Broome, Galathea3 Expedition). found in several coral reef-dwelling fish orders, and many species are known from museum specimens only (Møller \& Schwarzhans, 2008). As efficient predators in these very microhabitats, viviparous sea snakes can be used as bioindicator for secretive fish that are otherwise impossible to observe and monitor.

There is therefore an urgent need for more collection, for example when tissue--samples and stomach contents are taken from sea snakes before preservation, so that molecular/genetic analyses can be used to confirm and further explore the feeding biology and dietary diversity of sea snakes. A promising alternative method to laborious collection of rare and cryptic reef fish is the use of sea snakes as "sample catchers" as mentioned above; sea snake feeding studies should focus on the analysis of sea snake gut contents, so as to establish their natural dietary niche breadth (Udyawer et al., 2018).

\section{Sexual dimorphism and diet in sea snakes}

In sea kraits, body and head sizes are larger in females than in males (Shine et al., 2002b). This sexual dimorphism is probably an adaptation to a sex-related divergence in prey size, as females eat larger eels than do males (Shetty \& Shine, 2002b; Shine et al., 2002a).

Viviparous sea snakes also show sexual dimorphism in size, females growing larger than males (Burns \& Heatwole, 2000; Shine et al., 2019), but further sexual dimorphism also exists, for example in scale rugosity and tail size (Avolio et al., 2006; Crowe-Riddell et al., 2016; Shine et al., 2019; Shine et al., 2003). Because different sexes target different life stages of prey, we would expect that a change in sex ratio of viviparous sea snakes might indicate a concomitant shift in prey life history.

The concept of the ecological niche is part of an influential body of general ecological theory addressing species' coexistence in resource--limited and competition-structured communities (Amarasekare, 2003; Hutchinson, 1978; Jeffries \& Lawton, 1984; Schluter, 2000). Viviparous sea snakes, especially members of the genus Hydrophis, include many species with sympatric, partially- or completely overlapping distributions and similar habitat preferences (Sanders et al., 2013a). However, the partitioning of resources (such as diet, nest sites, resting sites and breeding sites) among such species is a topic of major interest, which is not well understood at present (Dunson \& Minton, 1978; Lukoschek et al., 2007a; Udyawer et al., 2018). Substantial morphological variation in body and relative head size have been documented among some cooccurring species (Sherratt et al., 2018, 2019). Within the genera Microcephalophis and Hydrophis, extremely small-headed (microcephalic) species co-occur with large-headed 


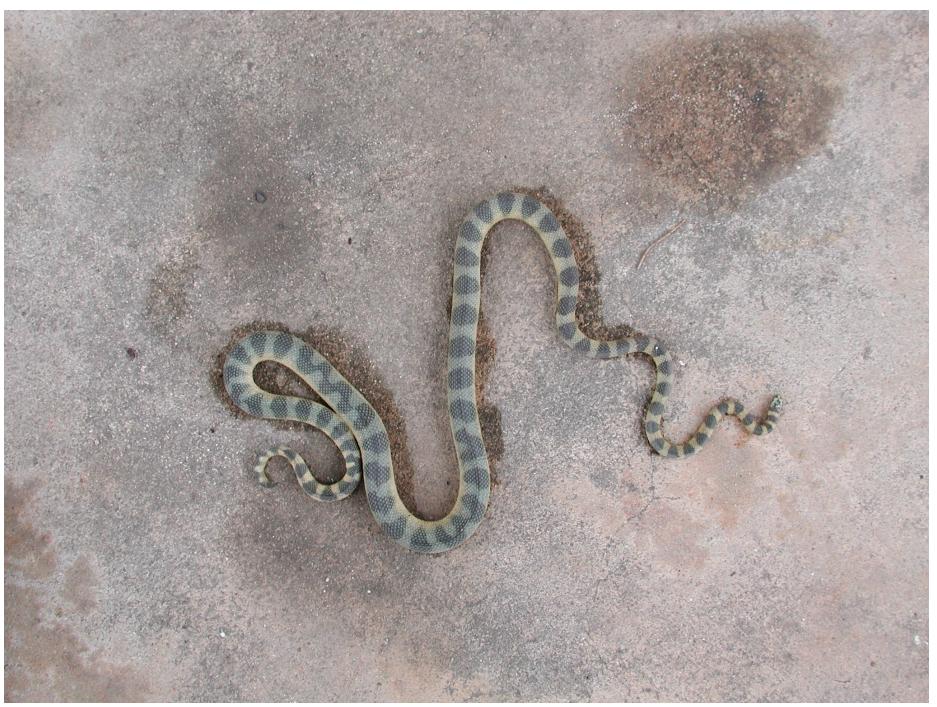

Figure 3. Hydrophis brookii, a small-headed (microcephalic) species (Songkhla Lake, Thailand).

(macrocephalic) species, a major body-plan difference apparently related to foraging mode and prey type variation (Sanders et al., 2013a) (Fig. 3). Therefore, viviparous sea snakes are well suited to test predictions about diet overlap and feeding niche segregation, likely increasing their value as bioindicators. A new model for rapid speciation and ecomorph differentiation in sea snakes was published by Sanders et al. (2013a) further suggesting the promise of viviparous sea snakes as a model study system for interface of community ecology and speciation theory.

Despite this, we still need information about ecology and natural history, but we regard Criterion 2 as fulfilled.

\section{Criterion 3: easy to survey}

All species of sea kraits can be observed on coral reefs and land; the most terrestrial species Laticauda colubrina and its closest relatives are the ones most often seen a bit inland from the seashore proper (Heatwole et al., 2005; Liu et al., 2012). When on land, these snakes prefer downwind shores, sheltered harbors, rocky jetties, cavities, and crevices (Bonnet et al., 2009; Liu et al., 2012). Some species are adapted to climbing and can be found on top of cliffs and in trees (Bonnet et al., 2016).

Viviparous sea snakes, on the other hand, with few exceptions, spend all their time in water. The exceptions include three semiaquatic species (Hydrelaps darwiniensis, Parahydrophis mertoni and Ephalophis greyi), which are also found on mudflats during low tide. Sea snakes that inhabit coral reefs and lagoons can be surveyed by travelling slowly (at about four knots) in a small boat and visually identifying snakes observed within $3 \mathrm{~m}$ of the path of the boat and to a depth of up to $3 \mathrm{~m}$ if the water is not turbid (A.R. Rasmussen, pers. obs.). At low tide, surveys can be conducted on foot, for example by searching reef flats (Guinea \& Whiting, 2005). Also, baited remote underwater video station samplings have been used to investigate the distribution of viviparous sea snakes (Udyawer et al., 2014). The results from this technique were very promising and in congruence with previous trawl and underwater visual surveys. Monitoring viviparous sea snakes using passive acoustic monitoring is also very useful (Udyawer et al., 2016b) and can provide information about home range, spatial movement, and habitat selection (Udyawer et al., 2018).

At night many viviparous sea snakes can be observed on the water's surface, rendering them convenient to survey from small boats equipped with a strong light. This method permits easy catching of sea snakes by use of nets, with little risk of injury for snake or handler. This method can be quite successful in turbid waters such as rivers and estuaries (Porter et al., 1997) and even at sea (Bonnet et al., 2016; Buzas et al., 2019; RezaieAtagholipour et al., 2016). Other methods for catching sea

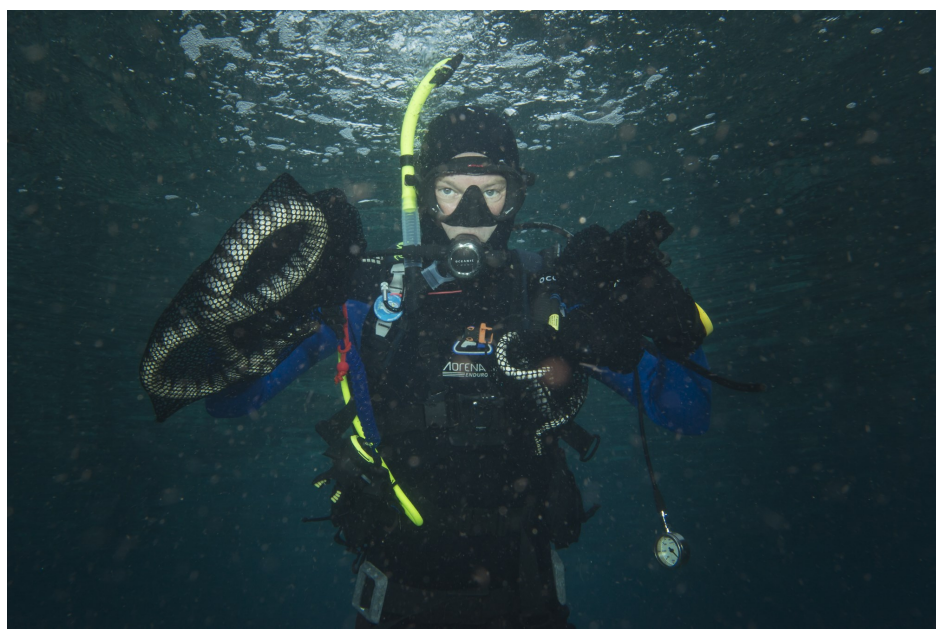

Figure 4. Diving in clear water during the day is an excellent way to catch sea snakes (Photo: Erik Frausing).

snakes involve diving or snorkelling in clear water during the day (Bonnet et al., 2016; Heatwole et al., 1978) (Fig. 4).

Finally, the use of environmental DNA (eDNA) as a monitoring tool for the presence/absence of species has gained tremendous momentum in recent years (Foote et al., 2012; Thomsen et al., 2012; Thomsen et al., 2016; Valentini et al., 2016). By extracting DNA directly from water or sediment samples, it is possible to PCR-amplify and sequence speciesspecific DNA markers ('barcodes') such as segments of the highly variable mitochondrial gene cytochrome B (cytB). Although this technology is still in a somewhat explorative phase where validation criteria and caveats must be thoroughly 
established, it is clear that there is great potential for its use in monitoring - even for animals such as viviparous sea snakes which rarely occur in high densities. First and foremost, however, this method requires DNA sequence reference databases with sufficient data/taxon coverage to allow identification of eDNA sequences to the level of sea snake species. Fortunately, extensive $c y t B$ sampling for sea snakes is available in Genbank (Lee et al., 2016; Sanders et al., 2013b).

Thus, the above-mentioned established methods to survey and catch sea snakes are easy to implement and we regard Criterion 3 as fulfilled.

\section{Criterion 4: higher taxa widely distributed geographically and over a breadth of habitat}

Globally there are some 63 species of viviparous sea snakes found in the tropical and subtropical waters of the Indian Ocean and the Pacific Ocean, from the east coast of Africa to the Gulf of Panama (David \& Ineich, 1999; Nankivell et al., 2020; Rasmussen et al., 2011c). Most species are found in the Indo-Malayan Archipelago, the China Sea, Indonesia and the Australian region (David \& Ineich, 1999; Heatwole et al., 2005; Kharin \& Czeblukov, 2009; Nankivell et al., 2020; Rasmussen, 1992; Rasmussen et al., 2011ab, 2014; Smith, 1926; see also Elfes et al., 2013 for a global species richness map of viviparous sea snakes). The historical biogeography of viviparous sea snakes has been inferred for some taxa believed to have expanded from the Australian region into Asia and then back again (Ukuwela et al., 2016; Ukuwela et al., 2017). There is only one truly pelagic sea snake (Hydrophis platurus), and it has the widest range of all sea snakes. Hydrophis platurus is found both in the Pacific and Indian Oceans, and a few specimens have been observed in the Atlantic Ocean (Bessesen \& Galbreath, 2017; Branch, 1998). Other species, such as $H$. caerulescens, $H$. cyanocinctus, $H$. curtus $H$. ornatus, H. peronii, $H$. spiralis, and $H$. stokesii have a very wide distribution in both Asia as well as in the Australian region ((Buzas et al., 2019; David \& Ineich, 1999; Gritis \& Voris, 1990; Ineich \& Rasmussen, 1997; Rasmussen et al., 2014; Rezaie-Atagholipour et al., 2016). With their wide distribution some viviparous sea snake species have potential for use in existing monitoring programs across these regions. Other species, however, are known only from very restricted areas: $H$. laboutei only at Chesterfield Reef (Rasmussen \& Ineich, 2000), H. parviceps from a very restricted area in south Vietnam (Rasmussen et al., 2012), H. semperi from Taal Lake in the Philippines (Garcia et al., 2014), and $H$. sibauensis from a limited area, more than $1000 \mathrm{~km}$ up-river from the coast in the Sibau River (an affluent Kapuas River, on Borneo Island; Rasmussen et al., 2001).
Over the last 40 years a large number of new distributional records have been added and about 11 new sea snake species have been described (Cogger \& Heatwole, 2006; Dotsenko, 2011; Heatwole et al., 2005; Kharin, 1983, 1984, 1985, 2005; Nankivell et al., 2020; Rasmussen et al., 2001; Rasmussen \& Ineich, 2000; Rasmussen et al., 2011c; Sanders et al., 2012a; Ukuwela et al., 2012). We can expect that more species still will be described in the future, as many areas suitable for sea snakes have not yet been explored, especially those between the two hotspot areas in the South China Sea and Northern Australia (Elfes et al., 2013). Moreover, some of the known species may harbor morphologically cryptic species in less well studied parts of their geographical range (D'Anastasi et al., 2016; Sanders et al., 2015; Udyawer et al., 2018).

The majority of observation involving viviparous sea snakes are made at depths less than $100 \mathrm{~m}$ (Greer, 1997); however, a few observations of specimens have been recorded as deep as $245 \mathrm{~m}$ (Crowe-Riddell et al., 2019). Some species are found in shallow waters in and around coral reefs, (Emydocephalus spp.; Alcala et al., 2000; Lukoschek \& Shine, 2012; Fig. 5). Others are restricted to mangroves in and on mudflats (Hydrelaps darwiniensis; Sweet, 1989). Some species seasonally occur in rivers and river mouths (e.g., H. brookii, $H$. melanosoma, H. obscurus $H$. schistosus, and H. torquatus; Voris, 2015), whereas others are recorded most often in deeper water (e.g., H. curtus, H. cyanocinctus, H. laboutei, H. ornatus, H. ocellatus, H. spiralis and H. czeblukovi; Buzas et al., 2019; Cao et al., 2014; Smith, 1974). Some recent studies indicate that species in the Aipysurus Group have a more distinct geographical population structure compared with species in the Hydrophis Group, which have intraspecific population differentiation lacking geographically-based genetic structure

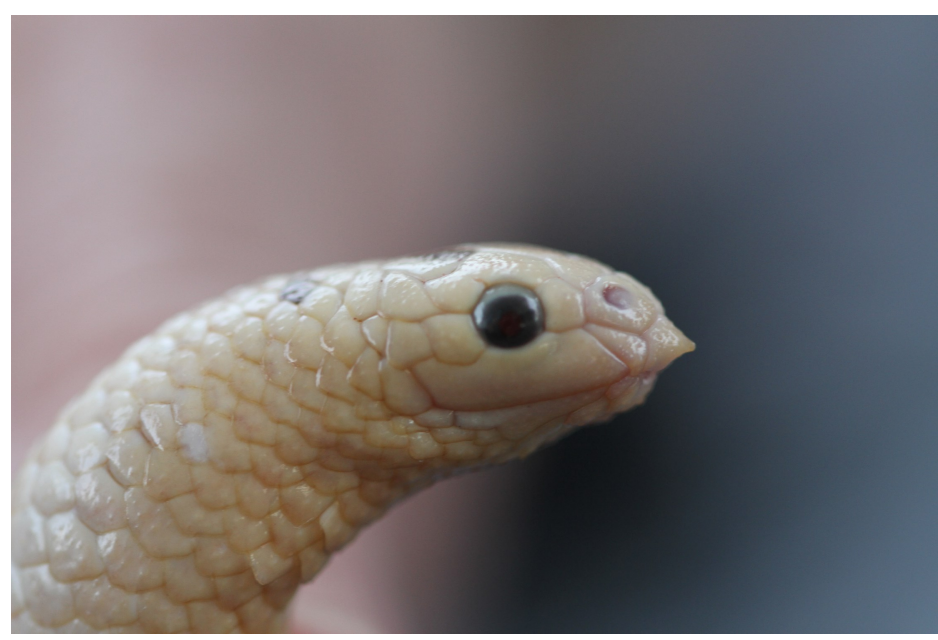

Figure 5. Characteristic head of Emydocephalus annulatus, normally found in shallow waters around and in coral reefs forage for fish eggs (Scotts Reef, Australia). 
(Lukoschek et al., 2007a; Lukoschek \& Shine, 2012; Nitschke et al., 2018). Most species in the Hydrophis Group are found in a variety of microhabitat types, such as soft sediment habitats, sea grass beds, marine gravel bottoms, rivers, and river mouths. Species of the Aipysurus Group also occur in a variety of coral reef and sand bottom marine habitats, but less frequently in riverine microhabitats (Cogger, 2000; Heatwole, 1999; Lukoschek et al., 2013; Porter et al., 1997; Rasmussen, 1987).

In summary, viviparous sea snakes are undoubtedly widely distributed, with substantial variation in range size among species. Collectively, they utilize a breadth of marine and estuarine habitats and, at the same time, some species are microhabitat generalists whereas others are more specialist.

Consequently, we argue that viviparous sea snakes meet Criterion 4 for use as bioindicators.

\section{Criterion 5: diverse number of species specialised and sensitive to habitat changes}

Some investigations in New Caledonia indicate that species of Laticauda are very sensitive to environmental change and pollution from dense human populations (Goiran et al., 2017; Goiran \& Shine, 2013). Specific information on habitat use primarily is limited to Australia and New Caledonia (Brischoux et al., 2011b; Brischoux \& Shine, 2011; Dunson, 1975; Karthikeyan \& Balasubramanian, 2008; Lukoschek et al., 2007b; Padate et al., 2009; Shine, 2005), complemented by a few interesting studies from Asia (Voris, 2015). Most species occur in shallow habitats such as coral reefs, muddy or sandy areas, sea grass beds, mangroves, river mouths or rivers, lakes, or rocky areas.

A recent case study indicates that viviparous sea snakes are very sensitive to environmental changes; Ashmore Reef in the Timor Sea was long regarded as a hotspot for viviparous sea snake diversity with at least 14 recorded species (Guinea, 1995; Guinea \& Whiting, 2005; Minton \& Heatwole, 1975; Smith, 1926). However, by the late 1990 s or early 2000 s, species began to disappear from the reef and during a survey in 2010 (Lukoschek et al., 2013) only two species were recorded ( $A$. laevis and H. stokesii) and follow-up surveys in 2012 and 2013 found no sea snakes (Guinea, 2013; Sanders et al., 2014) demonstrating a dramatic decline. The disappearance of 14 species from a single reef in such a short time (Elfes et al., 2013; Lukoschek, 2018b; Lukoschek et al., 2013) is a mystery. Bycatch, pollution, and seabed changes due to trawling are all known to affect sea snake numbers negatively. None of the above disturbances occurred in Ashmore Reef, giving no explanation for the disappearance of so many species. However, in a presentation at the World Congress of Herpetology (2020),
M. Guinea suggested that human disturbance may be to blame, further indicating that sea snakes may be sensitive to environmental change as an 'early warning' system for unknown processes as indicators of localized ecosystem change. In selected areas in Australia, commercial sea snake fisheries and by-catch have been studied during the past 30 years, indicating a similar negative impact of these activities as in other areas (Fry et al., 2001; Heales et al., 2008; Ward, 1996, 2000; Wassenberg et al., 2001; Wassenberg et al., 1994; Zhou et al., 2012).

Studies in the South China Sea indicate that sea snakes have declined as well; in the Gulf of Thailand, populations disappeared from rivers (Hydrophis torquatus, H. klossi; Rasmussen et al., 2011a). Also, on the island of Borneo, the number of specimens (collected previously in great numbers at river mouths) appears to have declined (A.R. Rasmussen, pers. obs. 2005). Trawl fisheries in the Andaman Sea catch fewer specimens in recent years, and fishers state that snake size has declined, indicating possible habitat degradation (Phuket Port; Rasmussen, 1997). A small 2000/2001 survey in Cambodia suggested similar results (A.R. Rasmussen, unpublished data).

In conclusion, many indications of sea snake population sensitivity to habitat change are apparent. Combined with the fact that numerous microhabitat- and diet-specialized species exist, leads us to argue that Criterion 5 is met as well.

\section{Criterion 6: patterns observed in indicator taxa are also observed in other related and unrelated taxa}

As mentioned before, there are large marine areas hosting viviparous sea snakes that are under great anthropogenic pressure due to habitat destruction, pollution, over-fishing, and climate change (Elfes et al., 2013). This will without doubt also negatively affect other related and unrelated taxa, such as water snakes (Homalopsidae), wart snake (Acrochordidae), burrowing eels (Anguilliformes) and corals (Anthony, 2016; Arvedlund, 2009; de Silva et al., 2010; Kannan et al., 2019; Murphy, 2007). Longitudinal datasets for viviparous sea snakes are available from multiple locations (Ashmore Reef, New Caledonia, Malacca Strait) and these can be utilized to examine for correlations with changes in population size, relative abundances, and demography of secretive fish species (Goiran $\&$ Shine, 2013; Lukoschek et al., 2013; Shine et al., 2019; Voris, 1985, 2015).

Combining diet data from viviparous sea snakes with occurrence data of threatened fish species (e.g., IUCN Red List) is also a possible way to meet Criterion 6 .

\section{Criterion 7: present or potential economic importance}




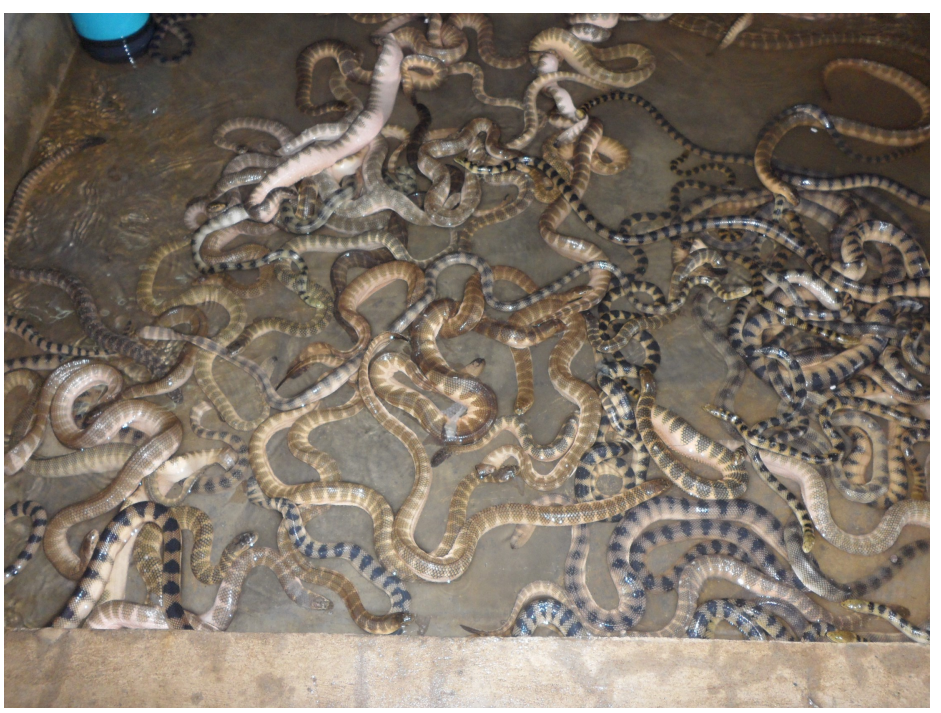

Figure 6. Sea snakes collected alive by Vietnamese fishermen for export to China (Cao et al., 2014).

"The sociological justification associated with indicator species is often one that requires mollification more than major economic impact. Without minimizing the significance of this criterion, even economic potential and minimal economic impact may be sufficient to rebut objections that might have eliminated an otherwise ideal indicator taxon" (Pearson, 1994).

Since at least 1934, sea snake meat and skins have been used commercially in the Philippines (Bacolod, 1990), Australia, Japan, Taiwan, Thailand, and Vietnam (Padate et al., 2009; Rasmussen et al., 2011a; Warrell, 1994; Wassenberg et al., 2001; Fig. 6). Vietnam squid fishermen alone harvest 82 tons of viviparous sea snakes annually in the Gulf of Thailand, roughly equal to 225,500 individual sea snakes (Cao et al., 2014). To our knowledge this constitutes one of the largest harvest activities of venomous snakes and marine reptiles in the world today.

Obviously, Criterion 7 is fulfilled when it comes to sea snakes. However, most sea snake fisheries in the Indian Ocean and in the Pacific are neither monitored nor reported in the literature and are thus beyond the control of local governments and conservation agencies. We therefore recommend that further studies also focus on the economic use of sea snakes and its impact on populations.

\section{Conclusions}

Previous investigations of sea kraits as bioindicators show that they are excellent for surveying Anguilliform fish assemblages in coral reefs (Brischoux et al., 2007ab, 2009a; Ineich et al., 2007). Sea kraits thus meet several of the bioindicator criteria discussed above, but we argue that viviparous sea snakes have even better prospects of being good bioindicators because: 1) they have a wide distribution in tropical and subtropical waters of the Indian and Pacific Oceans (David \& Ineich, 1999; Rasmussen et al., 2011a; Ukuwela et al., $2016)$; 2) the group includes feeding specialists and generalists (Heatwole, 1999; McCosker, 1975; Rasmussen, 2001; Voris \& Voris, 1983; Voris et al., 1978), 3) there are many specialized species, but the group as a whole covers a broad range of marine feeding niches (Cogger, 1975, 1992; Heatwole \& Cogger, 1994; Heatwole et al., 1974; Lukoschek et al., 2007a; Rasmussen \& Ineich, 2010; Sanders et al., 2010, 2012b), and 4) we know that they are affected by anthropogenic activities.

A further advantage of using viviparous sea snakes as bioindicators is that, being active and efficient predators, they "sample" and thus assess the diversity and the abundance of many secretive fish groups occurring in a variety of marine habitats (estuaries, sandy bottoms, muddy bottoms, as well as in coral reefs and rocky substrates). Another fundamental advantage is that viviparous sea snakes are easy to catch when they come to the surface to rest and breathe, permitting monitoring at low cost and requiring only simple equipment (Bonnet et al., 2016; Brischoux \& Bonnet, 2008; Buzas et al., 2019; Porter et al., 1997; Rasmussen \& Hay-Schmidt, 2008). In waters with high visibility, such as coral reefs and shallow sandy bottoms, viviparous sea snakes are easy to catch and handle, even when researchers themselves are submerged (Bonnet et al., 2016; Brischoux et al., 2009a; Guinea \& Whiting, 2005; Heatwole et al., 1978; Rasmussen \& Elmberg, 2009; Shine et al., 2003, 2004).

We argue that viviparous sea snakes have great potential as bioindicators for monitoring marine habitats during this time of great climate change, habitat change and loss, decline in biodiversity, and other anthropogenic changes. This effort will require deeper knowledge of the taxonomy of some groups, their breeding and feeding biology, habitat selection, and distribution. However, we assert that even given our current knowledge limitations, viviparous sea snakes should be considered as suitable bioindicators of marine ecosystem health.

\section{Acknowledgement}

Thanks to Professor Angel C. Alcala for his many inspiring scientific contributions to biodiversity conservation in marine biology and herpetology. Thanks also to DANIDA for support during surveys in Cambodia, India, Sulawesi, Thailand and Vietnam. Knud Højgaards Fund, Swedish Orphan International $\mathrm{AB}$, the Danish Research Council (Kulturministeriets Forskningpulje) for support during the 
Galathea3 expedition and The Carlsberg Fund for support during surveys in Sulawesi and New Guinea and the Research Council at KADK, School of Conservation for travel support. Erik Frausing, Henrik Agner and The Danish Navy and scientific members on board "Vaedderen" are gratefully acknowledged for help in collecting sea snakes. We are also grateful to the three anonymous reviewers for improving the manuscript.

\section{Literature Cited}

Alcala, A.C., 1986. Amphibians and reptiles. Guide to Philippine Flora and Fauna, 10: 1-195.

Alcala, A.C., J.P. Maypa \& G.R. Russ, 2000. Distribution of the turtle-headed sea snakes Emydocephalus n. sp. on coral reefs of the central Philippines. UPV Journal for Natural Sciences, 5: 27-32.

Alcala, A.C. \& G.R. Russ, 1990. A direct test of the effects of protective management on abundance and yield of tropical marine resources. ICES Journal of Marine Science, 47: 4047.

Alcala, A.C. \& G.R. Russ, 2006. No-take marine reserves and reef fisheries management in the Philippines: a new people power revolution. AMBIO: A Journal of the Human Environment, 35: 245-255.

Amarasekare, P., 2003. Competitive coexistence in spatially structured environments: a synthesis. Ecology Letters, 6: 1109-1122.

Anthony, K.R., 2016. Coral reefs under climate change and ocean acidification: challenges and opportunities for management and policy. Annual Review of Environment and Resources, 41: 59-81.

Arvedlund, M., 2009. First records of unusual marine fish distributions--can they predict climate changes? Journal of the Marine Biological Association of the United Kingdom, 89: 863-866.

Avolio, C., R. Shine \& A.J. Pile, 2006. Sexual dimorphism in scale rugosity in sea snakes (Hydrophiidae). Biological Journal of the Linnean Society, 89: 343-354.

Bacolod, P.T., 1983. Reproductive biology of two sea snakes of the genus Laticauda from central Philippines. Philippine Scientist, 20: 39-56.

Bacolod, P.T., 1990. The biology of some commercially important species of sea snakes (Hydrophiidae) in the Visayan Sea. Philippine Scientist, 27: 61-88.

Bergman, A.M., 1943. The breeding habits of sea snakes. Copeia, 1943: 156-160.
Bessesen, B.L. \& G.J. Galbreath, 2017. A new subspecies of sea snake, Hydrophis platurus xanthos, from Golfo Dulce, Costa Rica. ZooKeys, 686: 109-123.

Bilton, D.T., L. Mcabendroth, A. Bedford \& P.M. Ramsay, 2006. How wide to cast the net? Cross-taxon congruence of species richness, community similarity and indicator taxa in ponds. Freshwater Biology, 51: 578-590.

Bishop, J.M. \& A.H. Alsaffar, 2008. Quantitative observations on marine mammals and reptiles of Kuwait's Boubyan Island. Zoology in the Middle East, 43: 3-12.

Bonnet, X., 2012. Long-term field study of sea kraits in New Caledonia: fundamental issues and conservation. Integrative and Comparative Biology, 52: 281-295.

Bonnet, X., F. Brischoux, C. Bonnet, P. Plichon \& T. Fauvel, 2014. Coastal nurseries and their importance for conservation of sea kraits. PLos One, 9: e90246.

Bonnet, X., F. Brischoux, D. Pearson \& R. Rivalan, 2009. Beach rock as a keystone habitat for amphibious sea snakes. Environmental Conservation, 36: 62-70.

Bonnet, X., A.R. Rasmussen \& F. Brischoux, 2016. Sea snakes. In: Dodd, C.K. (ed), Reptile Ecology and Conservation:. Oxford University Press, Oxford. pp. 154-167.

Branch, B., 1998. Field guide to the snakes and other reptiles of southern Africa. Sanibel Island, Florida: Ralph Curtis Books Publishing. 399 pp.

Briers, R.A. \& J. Biggs, 2003. Indicator taxa for the conservation of pond invertebrate diversity. Aquatic Conservation: Marine and Freshwater Ecosystems, 13: 323 -330 .

Brischoux, F. \& X. Bonnet, 2008. Estimating the impact of sea kraits on the anguilliform fish community (Congridae, Muraenidae, Ophichthidae) of New Caledonia. Aquatic Living Resources, 21: 395-399.

Brischoux, F. \& X. Bonnet, 2009. Life history of sea kraits in New Caledonia. Memoires du Museum national d'Histoire naturelle (France), 198: 133-147.

Brischoux, F., X. Bonnet \& M. De Crignis, 2007a. A method to reconstruct anguilliform fishes from partially digested items. Marine Biology, 151: 1893-1897.

Brischoux, F., X. Bonnet \& P. Legagneux, 2009a. Are sea snakes pertinent bio-indicators for coral reefs? a comparison between species and sites. Marine Biology, 156: 1985-1992.

Brischoux, F., X. Bonnet \& R. Shine, 2007b. Foraging ecology of sea kraits Laticauda spp. in the Neo-Caledonian Lagoon. Marine Ecology Progress Series, 350: 145-151.

Brischoux, F., X. Bonnet \& R. Shine, 2009b. Determinants of dietary specialization: a comparison of two sympatric species of sea snakes. Oikos, 118: 145-151. 
Brischoux, F., X. Bonnet \& R. Shine, 2011b. Conflicts between feeding and reproduction in amphibious snakes (sea kraits, Laticauda spp.). Austral Ecology, 36: 46-52.

Brischoux, F., G.E. Gartner, T. Garland \& X. Bonnet, 2011a. Is aquatic life correlated with an increased hematocrit in snakes? PLos One, 6: e17077.

Brischoux, F. \& R. Shine, 2011. Morphological adaptations to marine life in snakes. Journal of Morphology, 272: 566572.

Brongersma, L.D., 1956. Notes on New Guinea reptiles and amphibians V. Proceedings of the Koninklijke Nederlandse Akademie van Wetenschappen. Series C Biological and Medical Sciences, 59: 599-610.

Burns, G. \& H. Heatwole, 2000. Growth, sexual dimorphism, and population biology of the olive sea snake, Aipysurus laevis, on the Great Barrier Reef of Australia. AmphibiaReptilia, 21: 289-300.

Bussarawit, S., A.R. Rasmussen \& M. Andersen, 1989. A preliminary study on sea snakes from Phuket Habour, Phuket Island, Thailand. Natural History Bulletin of the Siam Society, 37: 209-225.

Buzas, B., B. Farkas, E. Gulyás \& C. Géczy, 2019. The sea snakes (Elapidae: Hydrophiinae) of Fujairah. Tribulus, 26: 4-31.

Cao, N.V., B.H. Long, K. Broad \& A.R. Rasmussen, 2017. Sea snakes in Vietnam, Ran Bien. Wildlife at Risk, 2017: 1-62.

Cao, N.V., N.T. Tao, A. Moore, A. Montoya, A.R. Rasmussen, K. Broad, H.K. Voris \& Z. Takacs, 2014. Sea snake harvest in the Gulf of Thailand. Conservation Biology, 28: 16771687.

Carignan, V. \& M.A. Villard, 2002. Selecting indicator species to monitor ecological integrity: a review. Environmental Monitoring and Assessment, 78: 45-61.

Carpenter, K.E., F. Krupp, D.A. Jones \& U. Zajonz, 1997. FAO species identification field guide for fishery purposes. The living marine resources of Kuwait, Eastern Saudi Arabia, Bahrain, Qatar, and the United Arab Emirates. Rome, FAO. $293 \mathrm{pp}$.

Cherel, Y. \& K.A. Hobson, 2007. Geographical variation in carbon stable isotope signatures of marine predators: a tool to investigate their foraging areas in the Southern Ocean. Marine Ecology Progress Series, 329: 281-287.

Cogger, H.G., 1975. Sea Snakes of Australia and New Guinea. In: Dunson, W.A. (ed), The Biology of Sea Snakes. University Park Press, Baltimore London \& Tokyo. pp. 59139.

Cogger, H.G., 1992. Reptiles and Amphibians of Australia. Chatswood New South Wales and Cornell University Press, New York.: Reed International Books. 775 pp.
Cogger, H.G., 2000. Reptiles and Amphibians of Australia. Sanibel Island: Ralph Curtis Publishing. 808 pp.

Cogger, H.G. \& H. Heatwole, 2006. Laticauda frontalis (de Vis, 1905) and Laticauda saintgironsi $\mathrm{n}$. sp. from Vanuatu and New Caledonia (Serpentes: Elapidae: Laticaudinae) - a new lineage of sea kraits? Records of the Australian Museum 58: 245-256.

Crowe-Riddell, J.M., B.R. D'Anastasi, J.H. Nankivell, A.R. Rasmussen \& K.L. Sanders, 2019. First records of sea snakes (Elapidae: Hydrophiinae) diving to the mesopelagic zone (> 200 m). Austral Ecology, 44: 752-754.

Crowe-Riddell, J.M., E.P. Snelling, A.P. Watson, A.K. Suh, J.C. Partridge \& K.L. Sanders, 2016. The evolution of scale sensilla in the transition from land to sea in elapid snakes. Open Biology, 6: 1-12.

D'Anastasi, B.R., L. van Herwerden, J.A. Hobbs, C.A. Simpfendorfer \& V. Lukoschek, 2016. New range and habitat records for threatened Australian sea snakes raise challenges for conservation. Biological Conservation, 194: 66-70.

David, P. \& I. Ineich, 1999. Les serpents venimeux du monde: systématique et répartition. Dumerilia(Paris), 3: 3-499.

de Silva, A., P. Freed, J. Rudge, A.R. Rasmussen \& K.L. Sanders, 2010. Some observations on the wart snake Acrochordus granulatus (Schneider, 1799)(Squamata: Serpentes) in Sri Lanka. Lyriocephalus Special Issue, 7: 203 $-206$.

de Silva, A., K.D.B. Ukuwela, A. Sivaruban \& K.L. Sanders, 2011. Preliminary observations on the reproductive biology of six species of Sri Lankan sea snakes (Elapidae: Hydrophiinae). Salamandra, 47: 193-198.

Dotsenko, I.B., 2011. Emydocephalus szczerbaki sp. n. (Serpentes, Elapidae, Hydrophiidae) - a new species of the turtleheaded sea snake genus from Vietnam [In Russian]. Zbirnik prats' zoologichnogo museyu. Kiev, 41: 128-138 [2010].

Dudgeon, D., A.H. Arthington, M.O. Gessner, Z.I. Kawabata, D.J. Knowler, C. Lévêque, R.J. Naiman, A.H. PrieurRichard, D. Soto \& M.L.J. Stiassny, 2006. Freshwater biodiversity: importance, threats, status and conservation challenges. Biological Reviews, 81: 163-182.

Dunson, W.A., 1975. The Biology of Sea Snakes. Baltimore: University Park Press. 530 pp.

Dunson, W.A. \& S.A. Minton, 1978. Diversity, distribution, and ecology of Philippine marine snakes (Reptilia, Serpentes). Journal of Herpetology, 12: 281-286.

Elfes, C.T., S.R. Livingstone, A.M. Lane, V. Lukoschek, K.L. Sanders, A.J. Courtney, J.L. Gatus, M. Guinea, A. Lobo, D. Milton, A.R. Rasmussen, M. Read, M.D. White, J. 
Sanciangco, A.C. Alcala, H. Heatwole, D.R. Karns, J.A. Seminoff, H.K. Voris, K.E. Carpenter \& J.C. Murphy, 2013. Fascinating and forgotten: the conservation status of marine elapid snakes. Herpetological Conservation and Biology, 8: 37-52.

Ellis, S.L., L.S. Incze, P. Lawton, H. Ojaveer, B.R. MacKenzie, C.R. Pitcher, T.C. Shirley, M. Eero, J.W. Tunnell Jr., P.J. Doherty \& B.M. Zelle, 2012. Four regional marine biodiversity studies: approaches and contributions to ecosystem-based management. PLos One, 6: 1-21.

Fleishman, E., J.R. Thomson, R. Mac Nally, D.D. Murphy \& J.P. Fay, 2005. Using indicator species to predict species richness of multiple taxonomic groups. Conservation Biology, 19: 1125-1137.

Foote, A.D., P.F. Thomsen, S. Sveegaard, M. Wahlberg, J. Kielgast, L.A. Kyhn, A.B. Salling, A. Galatius, L. Orlando \& M.T.P. Gilbert, 2012. Investigating the potential use of environmental DNA (eDNA) for genetic monitoring of marine mammals. PLos One, 7: e41781.

Fry, G.C., D.A. Milton \& T.J. Wassenberg, 2001. The reproductive biology and diet of sea snake bycatch of prawn trawling in northern Australia: characteristics important for assessing the impacts on populations. Pacific Conservation Biology, 7: 55-73.

Ganesh, S.R., T. Nandhini, V.D. Samuel, C.R. Sreeraj, K.R. Abhilash, R. Purvaja \& R. Ramesh, 2019. Marine snakes of Indian coasts: historical resume, systematic checklist, toxinology, status, and identification key. Journal of Threatened Taxa, 11: 13132-13150.

Garcia, V.O.S., R.D.S. Papa, J.C.A. Briones, N. Mendoza, N. Okuda \& A.C. Diesmos, 2014. Food habits and distribution of the Lake Taal sea snake (Hydrophis semperi Garman 1881) and the sympatric Little File Snake (Acrochordus granulatus Schneider 1799) in Lake Taal, Philippines. Asian Herpetological Research, 5: 255-262.

Gherghel, I., M. Papeş, F. Brischoux, T. Sahlean \& A. Strugariu, 2016. A revision of the distribution of sea kraits (Reptilia, Laticauda) with an updated occurrence dataset for ecological and conservation research. ZooKeys, 2016: 135-148.

Glodek, G.S. \& H.K. Voris, 1982. Marine snake diets: prey composition, diversity and overlap. Copeia, 1982: 661-666.

Goiran, C., P. Bustamante \& R. Shine, 2017. Industrial melanism in the seasnake Emydocephalus annulatus. Current Biology, 27: 2510-2513. e2512.

Goiran, C. \& R. Shine, 2013. Decline in sea snake abundance on a protected coral reef system in the New Caledonian Lagoon. Coral Reefs, 32: 281-284.
Greer, A.E., 1997. The Biology and Evolution of Australian Snakes. Sydney, New South Wales, Australia: Surrey Beatty and Sons. 358 pp.

Gritis, P.A. \& H.K. Voris, 1990. Variability and significance of parietal and ventral scales in the marine snakes of the genus Lapemis (Serpentes: Hydrophiidae), with comments on the occurrence of spiny scales in the genus. Fieldiana Zoology, 56: 1-13.

Guinea, M.L., 1994. Sea snakes of Fiji and Niue. In: Gopalakrishnakone, P. (ed), Sea Snake Toxinology. Singapore University Press, pp. 212-233.

Guinea, M.L., 1995. The sea turtles and sea snakes of Ashmore Reef Nature Reserve. the Northern Territory University, Darwin. 67 pp.

Guinea, M.L., 2013. Surveys of the sea snakes and sea turtles on reefs of the Sahul Shelf Monitoring Program for the Montara Well Release Timor Sea Monitoring Study S6 Sea snakes/turtles. Draft Final Report 2012-2013: http:// www.environment.gov.au/system/files/pages/bcefac9b-ebc54013-9c88-a356280c202c/files/surveys-sea-snakesturtles.pdf.

Guinea, M.L. \& S.D. Whiting, 2005. Insights into the distribution and abundance of sea snakes at Ashmore Reef. The Beagle, 1: 199-206.

Heales, D.S., R. Gregor, J. Wakeford, Y.G. Wang, J. Yarrow \& D.A. Milton, 2008. Tropical prawn trawl bycatch of fish and seasnakes reduced by Yarrow Fisheye bycatch reduction device. Fisheries Research, 89: 76-83.

Heatwole, H., 1999. Sea Snakes. University of New South Wales Press, Sydney. 148 pp.

Heatwole, H., S. Busack \& H.G. Cogger, 2005. Geographic variation in sea kraits of the Laticauda colubrina complex (Serpentes: Elapidae: Hydrophiinae: Laticaudini). Herpetological Monographs, 19: 1-136.

Heatwole, H. \& H.G. Cogger, 1994. Sea snakes of Australia. In: Gopalakrishnakone, P. (ed), Sea Snake Toxinology. Singapore University Press, Singapore. pp. 167-205.

Heatwole, H., E. Heatwole \& C.R. Johnson, 1974. Shark predation on sea snakes. Copeia, 1974: 780-781.

Heatwole, H., S.A. Minton, R. Taylor \& V. Taylor, 1978. Underwater observations on sea snake behaviour. Records of the Australian Museum, 31: 737-761.

Heino, J., 2010. Are indicator groups and cross-taxon congruence useful for predicting biodiversity in aquatic ecosystems? Ecological Indicators, 10: 112-117.

Hindell, M.A., C.J.A. Bradshaw, R.G. Harcourt \& C. Guinet, 2003. Ecosystem monitoring: are seals a potential tool for monitoring change in marine systems? . In: Gales, N.J., M.A. Hindell \& R. Kirkwood (eds), Marine mammals. 
Fisheries, Tourism and Management Issues. CSIRO Publishing, Melbourne. pp. 330-343.

Hutchinson, G.E., 1978. An Introduction to Population Biology: Yale University Press. New Haven. 260 pp.

Ineich, I., X. Bonnet, F. Brischoux, M. Kulbicki, B. Seret \& R. Shine, 2007. Anguilliform fishes and sea kraits: neglected predators in coral-reef ecosystems. Marine Biology, 151: 793-802.

Ineich, I. \& P. Laboute, 2002. Sea snakes of New Caledonia / Les serpents marins de Nouvelle-Calédonie. Collection Faune et Flore Tropicales, 39: 1-302.

Ineich, I. \& A.R. Rasmussen, 1997. Sea snakes from New Caledonia and the Loyalty Islands (Elapidae, Laticaudinae and Hydrophiinae). Zoosystema, 19: 185-192.

Jeffries, M.J. \& J.H. Lawton, 1984. Enemy free space and the structure of ecological communities. Biological Journal of the Linnean Society, 23: 269-286.

Kannan, K., E. Kannapiran \& N. Prabhu, 2019. New geographical record of the moray eel Gymnothorax reticularis, Bloch, 1795 (Anguilliformes: Muraenidae) with taxonomic status and distribution from southwest coast of India. Thalassas: An International Journal of Marine Sciences, 35: 567-571.

Karthikeyan, R. \& T. Balasubramanian, 2008. Feeding and reproductive behavior of captive sea snakes Hydrophis cyanocinctus. Applied Herpetology, 5: 75-80.

Khan, M.S., 2004. Annotated checklist of amphibians and reptiles of Pakistan. Asiatic Herpetological Research, 10: 191-201.

Kharin, V.E., 1983. A new species of the genus Hydrophis sensu lato (Serpentes: Hydrophiidae) from the north Australian shelf. Zoologicheskii Zhurnal, 62: 1751-1753.

Kharin, V.E., 1984. Sea snakes of the genus Hydrophis sensu lato (Serpentes, Hydrophiidae). On taxonomic status of the New Guinean H. obscurus. Zoologicheskii Zhurnal, 63: 630 -632 .

Kharin, V.E., 1985. A new species of sea snakes of the genus Enhydrina (Serpentes, Hydrophiidae) from waters of New Guinea. Zoologicheskii Zhurnal, 64: 785-787.

Kharin, V.E., 2005. On new findings of a rare sea snake Leioselasma czeblukovi Kharin, 1984, with remarks on species composition and taxonomical position of the genus Leioselasma Lacepede, 1804, (Serpentes: Hydrophiidae). Russian Journal of Marine Biology, 31: 269-272.

Kharin, V.E. \& P.V. Czeblukov, 2006. A new revision of sea kraits of family Laticaudidae Cope, 1879 (Serpentes: Colubroidea) Russian Journal of Herpetology, 13: 227-241.

Kharin, V.E. \& V.P. Czeblukov, 2009. A revision of the sea snakes of subfamily Hydrophiinae. 1, tribe Disteirini nov.
(Serpentes: Hydrophiidae). Russian Journal of Herpetology, 16: $183-202$.

Kharin, V.E. \& V.P. Czeblukov, 2013. A new revision of sea kraits of family Laticaudidae Cope, 1879 (Serpentes: Colubroidea). Russian Journal of Herpetology, 13: 227-241.

Lee, M.S., K.L. Sanders, B. King \& A. Palci, 2016. Diversification rates and phenotypic evolution in venomous snakes (Elapidae). Royal Society Open Science, 3: 150277.

Lemen, C.A. \& H.K. Voris, 1981. A comparison of reproductive strategies among marine snakes. The Journal of Animal Ecology, 50: 89-101.

Leviton, A.E., R.M. Brown \& C.D. Siler, 2014. The dangerously venomous snakes of the Philippine Archipelago with identification keys and species accounts. In: Gary, G.C. \& T.M. Gosliner (eds), The Coral Triangle: The 2011 Hearst Philippine Biodiversity Expedition. California Academy of Sciences, San Francisco, California, USA. pp. 475-530.

Leviton, A.E., C.D. Siler, J.L. Weinell \& B.R. M., 2018. A synopsis of the snakes of the Philippines: a synthesis of data from biodiversity repositories, field studies, and the literature. Proceedings of the California Academy of Sciences 64: 399-568.

Liu, Y.L., Y.H. Chen, H.B. Lillywhite \& M.C. Tu, 2012. Habitat selection by sea kraits (Laticauda spp.) at coastal sites of Orchid Island, Taiwan. Integrative and Comparative Biology, 52: 274-280.

Lukoschek, V., 2018a. Congruent phylogeographic patterns in a young radiation of live-bearing marine snakes: Pleistocene vicariance and the conservation implications of cryptic genetic diversity. Diversity and Distributions, 24: 325-340.

Lukoschek, V., 2018b. Population declines, genetic bottlenecks and potential hybridization in sea snakes on Australia's Timor Sea reefs. Biological Conservation, 225: 66-79.

Lukoschek, V., M. Beger, D. Ceccarelli, Z. Richards \& M. Pratchett, 2013. Enigmatic declines of Australia's sea snakes from a biodiversity hotspot. Biological Conservation, 166: 191-202.

Lukoschek, V., H. Heatwole, A. Grech, G. Burns \& H. Marsh, 2007a. Distribution of two species of sea snakes, Aipysurus laevis and Emydocephalus annulatus, in the southern Great Barrier Reef: metapopulation dynamics, marine protected areas and conservation. Coral Reefs, 26: 291-307.

Lukoschek, V. \& J.S. Keogh, 2006. Molecular phylogeny of sea snakes reveals a rapidly diverged adaptive radiation. Biological Journal of the Linnean Society, 89: 523-539.

Lukoschek, V. \& R. Shine, 2012. Sea snakes rarely venture far from home. Ecology and Evolution, 2: 1113-1121.

Lukoschek, V., M. Waycott \& H. Marsh, 2007b. Phylogeography of the olive sea snake, Aipysurus laevis 
(Hydrophiinae) indicates Pleistocene range expansion around northern Australia but low contemporary gene flow. Molecular Ecology, 16: 3406-3422.

Mao, S.H. \& B.Y. Chen, 1980. Sea snakes of Taiwan. The National Science Council Special Publication, 4: 1-64.

Masunaga, G. \& H. Ota, 2003. Growth and reproduction of the sea snake, Emydocephalus ijimae, in the central Ryukyus, Japan: a mark and recapture study. Zoologica Scripta, 20: 461-470.

McCarthy, C.J., 1986. Relationships of the laticaudine sea snakes (Serpentes: Elapidae: Laticaudinae). Bulletin of the British Museum Natural History (Zoology), 50: 127-161.

McCosker, J.E., 1975. Feeding behavior of Indo-Australian Hydrophiidae. In: Dunson, W.A. (ed), The Biology of Sea Snakes. Baltimore: University Press Park. pp. 217-232.

McGeoch, M., 1998. The selection, testing and application of terrestrial insects as bioindicators. Biological Reviews, 73: 181-201.

Minton, S.A. \& H. Heatwole, 1975. Sea snakes from three reefs of Sahul shelf. In: Dunson, W.A. (ed), The Biology of Sea Snakes. Baltimore: University Park Press. pp. 141-144.

Mirtschin, P., A.R. Rasmussen \& S.A. Weinstein, 2017. Australia's dangerous snakes identification, biology and envenoming: CSIRO Publishing. 432 pp.

Murphy, J.C., 2007. Homalopsid Snakes: Evolution in the Mud. Evolution in the Mud Kreiger, Melbourne, FL. 249 pp.

Murphy, J.C., M.J. Cox \& H.K. Voris, 1999. A key to the sea snakes in the Gulf of Thailand. Natural History Bulletin of the Siam Society, 47: 95-108.

Møller, P.R. \& W. Schwarzhans, 2008. Review of the Dinematichthyini (Teleostei: Bythitidae) of the Indo-West Pacific. Part IV. Dinematichthys and two new genera with descriptions of nine new species. The Beagle, Records of the Museums and Art Galleries of the Northern Territory, 24: 87-146.

Nankivell, J.H., C. Goiran, M. Hourston, R. Shine, A.R. Rasmussen, V.A. Thomson \& K.L. Sanders, 2020. A new species of turtle-headed sea snake (Emydocephalus: Elapidae) endemic to Western Australia. Zootaxa, 4758: 141-156.

Niemelä, J., 2000. Biodiversity monitoring for decision-making. Annales Zoologici Fennici, 37: 307-317.

Nitschke, C.R., M. Hourston, V. Udyawer \& K.L. Sanders, 2018. Rates of population differentiation and speciation are decoupled in sea snakes. Biology Letters, 14: 1-6.

Noss, R.F., 1990. Indicators for monitoring biodiversity: a hierarchical approach. Conservation Biology, 4: 355-364.

Padate, V.P., L.V. Baragi \& C.U. Rivonker, 2009. Biological aspects of sea snakes caught incidentally by commercial trawlers off Goa, west coast of India. Journal of Threatened Taxa, 1: 609-616.

Pearson, D.L., 1994. Selecting indicator taxa for the quantitative assessment of biodiversity. Philosophical Transactions of the Royal Society of London. Series B: Biological Sciences, 345: 75-79.

Pearson, D.L. \& F. Cassola, 1992. World-wide species richness patterns of tiger beetles (Coleoptera: Cicindelidae): indicator taxon for biodiversity and conservation studies. Conservation Biology, 6: 376-391.

Pernetta, J.C., 1977. Observations on the habits and morphology of the sea snake Laticauda colubrina (Schneider) in Fiji. Canadian Journal of Zoology, 55: 1612-1619.

Porter, R., S. Irwin, T. Irwin \& K. Rodrigues, 1997. Records of marine snake species from The Hey-embley and Mission Rivers far North Queensland. Herpetofauna (Sydney), 27: 27.

Rasmussen, A.R., 1987. Persian Gulf sea snake Hydrophis lapemoides (Gray, 1849): New record from Phuket Island, Andaman Sea, and southern part of the Straits of Malacca. Natural History Bulletin of the Siam Society, 35: 57-58.

Rasmussen, A.R., 1989. An analysis of Hydrophis ornatus (Gray), H. lamberti Smith, and H. inornatus (Gray) (Hydrophiidae, Serpentes) based on samples from various localities, with remarks on feeding and breeding biology of H. ornatus. Amphibia-Reptilia, 10: 397-417.

Rasmussen, A.R., 1992. Rediscovery and redescription of Hydrophis bituberculatus Peters, 1872 (Serpentes: Hydrophidae). Herpetologica, 48: 85-97.

Rasmussen, A.R., 1997. Systematics of sea snakes: a critical review. Symposium of the Zoological Society of London 70: 15-30.

Rasmussen, A.R., 2001. Sea snakes. FAO species identification guide for fishery purposes//The living marine resources of the Western Central Pacific, 6: 3987-4008.

Rasmussen, A.R., 2002. Phylogenetic analysis of the "true" aquatic elapid snakes Hydrophiinae (sensu Smith et al. 1977) indicating two independent radiations into water. Steenstrupia, 27: 47-63.

Rasmussen, A.R., M. Auliya \& W. Böhme, 2001. A new species of the sea snake genus Hydrophis (Serpentes: Elapidae) from a river in West Kalimantan (Indonesia, Borneo). Herpetologica, 57: 23-32.

Rasmussen, A.R. \& J. Elmberg, 2009. 'Head for my tail': a new hypothesis to explain how venomous sea snakes avoid becoming prey. Marine Ecology, 30: 385-390.

Rasmussen, A.R., J. Elmberg, P. Gravlund \& I. Ineich, 2011 b. Sea snakes (Serpentes: subfamilies Hydrophiinae and 
Laticaudinae) in Vietnam: a comprehensive checklist and an updated identification key. Zootaxa, 2894: 1-20.

Rasmussen, A.R., J. Elmberg, K.L. Sanders \& P. Gravlund, 2012. Rediscovery of the rare sea snake Hydrophis parviceps Smith 1935: identification and conservation status. Copeia, 2012: 276-282.

Rasmussen, A.R. \& A. Hay-Schmidt, 2008. Giftige Havslanger. In: Jørgensen, L.N. (ed), Galathea 3 2006-2007. Narayana Press. pp. 178-180.

Rasmussen, A.R. \& I. Ineich, 2000. Sea snakes of New Caledonia and surrounding waters (Serpentes: Elapidae): first report on the occurrence of Lapemis curtus and description of a new species from the genus Hydrophis. Hamadryad, 25: 91-99.

Rasmussen, A.R. \& I. Ineich, 2010. Species diversity in the genus Emydocephalus Krefft, 1869 (Serpentes, Elapidae, Hydrophiinae): insight from morphology and anatomy. Herpetological Review, 41: 285-290.

Rasmussen, A.R., I. Ineich, J. Elmberg \& C. McCarthy, 2011c. Status of the Asiatic sea snakes of the Hydrophis nigrocinctus group (H. nigrocinctus, $H$. hendersoni, and $H$. walli; Elapidae, Hydrophiinae). Amphibia-Reptilia, 32: 459 -464 .

Rasmussen, A.R., J.C. Murphy, M. Ompi, J.W. Gibbons \& P. Uetz, 2011a. Marine reptiles. PLoS One, 6: 1-12.

Rasmussen, A.R., K.L. Sanders, M.L. Guinea \& A.P. Amey, 2014. Sea snakes in Australian waters (Serpentes: subfamilies Hydrophiinae and Laticaudinae) - a review with an updated identification key. Zootaxa, 3869: 351-371.

Reed, R.N., R. Shine \& S. Shetty, 2002. Sea kraits (Squamata: Laticauda spp.) as a useful bioassay for assessing local diversity of eels (Muraenidae, Congridae) in the western Pacific Ocean. Copeia, 2002: 1098-1101.

Rezaie-Atagholipour, M., P. Ghezellou, M.A. Hesni, S.M.H. Dakhteh, H. Ahmadian \& N. Vidal, 2016. Sea snakes (Elapidae, Hydrophiinae) in their westernmost extent: an updated and illustrated checklist and key to the species in the Persian Gulf and Gulf of Oman. ZooKeys, 2016: 129164.

Russ, G.R. \& A.C. Alcala, 2003. Marine reserves: rates and patterns of recovery and decline of predatory fish, 19832000. Ecological Applications, 13: 1553-1565.

Russ, G.R., B.J. Bergseth, J.R. Rizzari \& A.C. Alcala, 2015. Decadal-scale effects of benthic habitat and marine reserve protection on Philippine goatfish (F: Mullidae). Coral Reefs, 34: 773-787.

Saint Girons, H., 1990. Notes on ecology and population structure of the Laticaudinae (Serpentes, Hydrophidae) in
New Caledonia. Bulletin of the Chicago Herpetological Society, 25: 197-209.

Salas, F., J.M. Neto, A. Borja \& J.C. Marques, 2004. Evaluation of the applicability of a marine biotic index to characterize the status of estuarine ecosystems: the case of Mondego estuary (Portugal). Ecological Indicators, 4: 215-225.

Sanders, K.L., M.S.Y. Lee, R. Leys, R. Foster \& J.S. Keogh, 2008. Molecular phylogeny and divergence dates for Australasian elapids and sea snakes (Hydrophiinae): evidence from seven genes for rapid evolutionary radiations. Journal of Evolutionary Biology, 21: 682-695.

Sanders, K.L., M.S.Y. Lee, Mumpuni, T. Bertozzi \& A.R. Rasmussen, 2013b. Multilocus phylogeny and recent rapid radiation of the viviparous sea snakes (Elapidae: Hydrophiinae). Molecular Phylogenetics and Evolution, 66: 575-591.

Sanders, K.L., Mumpuni \& M.S.Y. Lee, 2010. Uncoupling ecological innovation and speciation in sea snakes (Elapidae, Hydrophiinae, Hydrophiini). Journal of Evolutionary Biology, 23: 2685-2695.

Sanders, K.L., A.R. Rasmussen, A. De Silva, N.A. Mumpuni \& D.B. Ukuwela, 2012b. Ecological innovation and speciation in viviparous sea snakes (Hydrophiinae). In: Society for Integrative and Comparative Biology Annual Meeting 3-7 January, Charleston, South Carolina.

Sanders, K.L., A.R. Rasmussen, J. Elmberg, Mumpuni, M. Guinea, P. Blias, M.S.Y. Lee \& B.G. Fry, 2012a. Aipysurus mosaicus, a new species of egg-eating sea snake (Elapidae: Hydrophiinae), with a redescription of Aipysurus eydouxii (Gray, 1849). Zootaxa, 3431: 1-18.

Sanders, K.L., A.R. Rasmussen \& M. Guinea, 2014. High rates of hybridisation reveal fragile reproductive barriers between endangered Australian sea snakes. Biological Conservation, 171: 200-208.

Sanders, K.L., A.R. Rasmussen, Mumpuni, J. Elmberg, A. de Silva, M.L. Guinea \& M.S. Lee, 2013a. Recent rapid speciation and ecomorph divergence in Indo-Australian sea snakes. Molecular Ecology, 22: 2742-2759.

Sanders, K.L., T. Schroeder, M.L. Guinea \& A.R. Rasmussen, 2015. Molecules and morphology reveal overlooked populations of two presumed extinct Australian sea snakes (Aipysurus: Hydrophiinae). PLoS One, 10: 1-13.

Schluter, D., 2000. The Ecology of Adaptive Radiation. Oxford: Oxford University Press. 296 pp.

Seret, B., F. Brischoux, X. Bonnet \& R. Shine, 2008. First record of Cirrimaxilla formosa (Teleostei: Muraenidae) from New Caledonia, found in sea snake stomach contents. Cybium, 32: 191-192. 
Sherratt, E., F.J. Coutts, A.R. Rasmussen \& K.L. Sanders, 2019. Vertebral evolution and ontogenetic allometry: the developmental basis of extreme body shape divergence in microcephalic sea snakes. Evolution \& Development, 2019: 1-10.

Sherratt, E., A.R. Rasmussen \& K.L. Sanders, 2018. Trophic specialization drives morphological evolution in sea snakes. Royal Society Open Science, 5: 1-8.

Shetty, S. \& R. Shine, 2002a. The mating system of yellowlipped sea kraits (Laticauda colubrina: Laticaudidae). Herpetologica, 58: 170-180.

Shetty, S. \& R. Shine, 2002b. Sexual divergence in diets and morphology in Fijian sea snakes Laticauda colubrina (Laticaudinae). Austral Ecology, 27: 77-84.

Shine, R., 2005. All at sea: aquatic life modifies materecognition modalities in sea snakes (Emydocephalus annulatus, Hydrophiidae). Behavioral Ecology and Sociobiology, 57: 591-598.

Shine, R., X. Bonnet, M.J. Elphick \& E.G. Barrott, 2004. A novel foraging mode in snakes: browsing by the sea snake Emydocephalus annulatus (Serpentes, Hydrophiidae). Functional Ecology, 18: 16-24.

Shine, R., R.N. Reed, S. Shetty \& H.G. Cogger, 2002b. Relationships between sexual dimorphism and niche partitioning within a clade of sea-snakes (Laticaudinae). Oecologia, 133: 45-53.

Shine, R., R.N. Reed, S. Shetty, M. Lemaster \& R.T. Mason, 2002a. Reproductive isolating mechanisms between two sympatric sibling species of sea snakes. Evolution, 56: 1655 -1662 .

Shine, R., T. Shine \& C. Goiran, 2019. Morphology, reproduction and diet of the greater sea snake, Hydrophis major (Elapidae, Hydrophiinae). Coral Reefs, 2019: 1-8.

Shine, R., T. Shine \& B. Shine, 2003. Intraspecific habitat partitioning by the sea snake Emydocephalus annulatus (Serpentes, Hydrophiidae): the effects of sex, body size, and colour pattern. Biological Journal of the Linnean Society, 80: 1-10.

Simboura, N. \& A. Zenetos, 2002. Benthic indicators to use in ecological quality classification of Mediterranean soft bottom marine ecosystems, including a new biotic index. Mediterranean Marine Science, 3: 77-112.

Slowinski, J.B., 1989. The interrelationships of laticaudine sea snakes based on the amino acid sequences of short-chain neurotoxins. Copeia, 1989: 783-788.

Smith, L.A., 1974. The sea snakes of Western Australia (Serpentes: Elapidae, Hydrophiinae), with a description of a new subspecies. Records of the Western Australian Museum, 3: 93-110.
Smith, M.A., 1926. Monograph of the Sea-Snakes (Hydrophiidae): Printed by Order of the Trustees of the British Museum (Natural History) London. 130 pp.

Somaweera, R. \& N. Somaweera, 2009. An overview of Sri Lankan sea snakes with an annotated checklist and a field key. Taprobanica, 1: 43-54.

Sutherland, W.J., W.M. Adams, R.B. Aronson, R. Aveling, T.M. Blackburn, S. Broad, G. Ceballos, I.M. Cote, R.M. Cowling \& G.A.B. Da Fonseca, 2009. One hundred questions of importance to the conservation of global biological diversity. Conservation Biology, 23: 557-567.

Sweet, S.S., 1989. Foraging behavior in the primitive sea snake Hydrelaps darwiniensis. In: 69th Annual Meeting American Society of Ichthyologists \& Herpetologists Abstract San Francisco State University and California Academy of Sciences, San Francisco, Califonia, p. 151.

Tabata, R., F. Tashiro, H. Nishizawa, J. Takagi, N. Kidera \& H. Mitamura, 2017. Stomach contents of three sea kraits (Hydrophiinae: Laticauda spp.) in the Ryukyu Islands, Japan. Current Herpetology, 36: 127-134.

Thomsen, P.F., J. Kielgast, L.L. Iversen, P.R. Møller, M. Rasmussen \& E. Willerslev, 2012. Detection of a diverse marine fish fauna using environmental DNA from seawater samples. PLoS One, 7: 1-9.

Thomsen, P.F., P.R. Møller, E.E. Sigsgaard, S.W. Knudsen, O.A. Jørgensen \& E. Willerslev, 2016. Environmental DNA from seawater samples correlate with trawl catches of subarctic, deepwater fishes. PLoS One, 11: 1-15.

Toriba, M. \& E. Nakamoto, 1987. Reproductive biology of erabu sea snake, Laticauda semifasciata (Reinwardt). The Snake, 19: 101-106.

Tu, M.C., S.C. Fong \& K.Y. Lue, 1990. Reproductive biology of the sea snake, Laticauda semifasciata, in Taiwan. Journal of Herpetology, 24: 119-126.

Udyawer, V., P. Barnes, X. Bonnet, F. Brischoux, J.M. CroweRiddell, B.R. D'Anastasi, B.G. Fry, A. Gillett, C. Goiran, M.L. Guinea, H. Heatwole, M.R. Heupel, M. Hourston, M. Kangas, A. Kendrick, I. Koefoed, H.B. Lillywhite, A.S. Lobo, V. Lukoschek, R. McAuley, C. Nitschke, A.R. Rasmussen, K.L. Sanders, C. Sheehy, R. Shine, R. Somaweera, S.S. Sweet \& H.K. Voris, 2018. Future directions in the research and management of marine snakes. Frontiers in Marine Science, 5: 1-16.

Udyawer, V., M. Cappo, C.A. Simpfendorfer, M.R. Heupel \& V. Lukoschek, 2014. Distribution of sea snakes in the Great Barrier Reef Marine Park: observations from $10 \mathrm{yrs}$ of baited remote underwater video station (BRUVS) sampling. Coral Reefs, 33: 777-791. 
Udyawer, V., M. Read, M. Hamann, M.R. Heupel \& C.A. Simpfendorfer, 2016b. Importance of shallow tidal habitats as refugia from trawl fishing for sea snakes. Journal of Herpetology, 50: 527-533.

Udyawer, V., C.A. Simpfendorfer, M. Read, M. Hamann \& M.R. Heupel, 2016a. Exploring habitat selection in sea snakes using passive acoustic monitoring and Bayesian hierarchical models. Marine Ecology Progress Series, 546: 249-262.

Ukuwela, K.D.B., M.S.Y. Lee, A.R. Rasmussen, A. De Silva, B.G. Fry, P. Ghezellou, M. Rezaie-Atagholipour \& K.L. Sanders, 2016. Evaluating the drivers of Indo-Pacific biodiversity: speciation and dispersal of sea snakes (Elapidae: Hydrophiinae). Journal of Biogeography, 43: 243-255.

Ukuwela, K.D.B., M.S.Y. Lee, A.R. Rasmussen, A. De Silva \& K.L. Sanders, 2017. Biogeographic origins of the viviparous sea snake assemblage (Elapidae) of the Indian Ocean. Ceylon Journal of Science, 46: 101-110.

Ukuwela, K.D.B., K.L. Sanders \& B.G. Fry, 2012. Hydrophis donaldi (Elapidae, Hydrophiinae), a highly distinctive new species of sea snake from Northern Australia. Zootaxa, 3201: 45-57.

Valentini, A., P. Taberlet, C. Miaud, R. Civade, J. Herder, P.F. Thomsen, E. Bellemain, A. Besnard, E. Coissac \& F. Boyer, 2016. Next-generation monitoring of aquatic biodiversity using environmental DNA metabarcoding. Molecular Ecology, 25: 929-942.

Vitousek, P.M., H.A. Mooney, J. Lubchenco \& J.M. Melillo, 1997. Human domination of earth's ecosystems. Science, 277: 494-499.

Voris, H.K., 1977. A phylogeny of the sea snakes (Hydrophiidae). Fieldiana Zoology, 70: 79-166.

Voris, H.K., 1985. Population size estimates for a marine snake (Enhydrina schistosa) in Malaysia. Copeia, 1985: 955-961.

Voris, H.K., 2015. Marine snake diversity in the mouth of the Muar River, Malaysia. Tropical Natural History, 15: 1-21.

Voris, H.K. \& B.C. Jayne, 1979. Growth, reproduction and population structure of a marine snake, Enhydrina schistosa (Hydrophiidae). Copeia, 1979: 307-318.

Voris, H.K. \& H.H. Voris, 1983. Feeding strategies in marine snakes: an analysis of evolutionary, morphological, behavioral and ecological relationships. American Zoologist, 23: 411-425.

Voris, H.K., H.H. Voris \& L.B. Liat, 1978. The food and feeding behavior of a marine snake, Enhydrina schistosa (Hydrophiidae). Copeia, 1978: 134-146.

Wall, F., 1921. Ophidia Taprobanica or the Snakes of Ceylon. Colombo: H. R. Cottle, Government printer. 1-581 pp.
Ward, T.M., 1996. Sea snake by-catch of fish trawlers on the Northern Australian continental shelf. Marine and Freshwater Research, 47: 625-630.

Ward, T.M., 2000. Factors affecting the catch rates and relative abundance of sea snakes in the by-catch of trawlers targeting tiger and endeavour prawns on the Northern Australian continental shelf. Marine and Freshwater Research, 51: 155-164.

Ward, T.M., 2001. Age structures and reproductive patterns of two species of sea snake, Lapemis hardwickii Grey(1836) and Hydrophis elegans (Grey 1842), incidentally captured by prawn trawlers in Northern Australia. Marine and Freshwater Research, 52: 193-203.

Warrell, D.A., 1994. Sea snake bites in the Asia-Pacific region. In: Gopalakrishnakone, P. (ed), Sea Snake Toxinology. Singapore University Press, Singapore. pp. 1-36.

Wassenberg, T.J., D.A. Milton \& C.Y. Burridge, 2001. Survival rates of sea snakes caught by demersal trawlers in northern and eastern Australia. Biological Conservation, 100: 271280.

Wassenberg, T.J., J.P. Salini, H. Heatwole \& J.D. Kerr, 1994. Incidental capture of sea-snakes (Hydrophiidae) by prawn trawlers in the Gulf of Carpentaria, Australia Australian Journal of Marine and Freshwater Research, 45: 429-443.

Weeks, R., G.R. Russ, A.C. Alcala \& A.T. White, 2010. Effectiveness of marine protected areas in the Philippines for biodiversity conservation. Conservation Biology, 24: 531-540.

Weinell, J.L., E. Hooper, A.E. Leviton \& R.M. Brown, 2019. Illustrated key to the snakes of the Philippines. Proceedings of the California Academy of Sciences 66: 1-49.

Wells, R.W., 2007. Some taxonomic and nomenclatural considerations on the class Reptilia in Australia. The sea snakes of Australia. An introduction to the members of the families Hydrophiidae and Laticaudidae in Australia, with a new familial and generic arrangement. Australian Biodiversity Record, 8: 1-124.

Zhou, S., D.A. Milton \& G.C. Fry, 2012. Integrated risk analysis for rare marine species impacted by fishing: sustainability assessment and population trend modelling. ICES Journal of Marine Science, 69: 271-280.

Zwickl, D.J., 2006. Genetic algorithm approaches for the phylogenetic analysis of large biological sequence datasets under the maximum likelihood criterion. University of Texas at Austin, Unpublished Ph.D. thesis. 